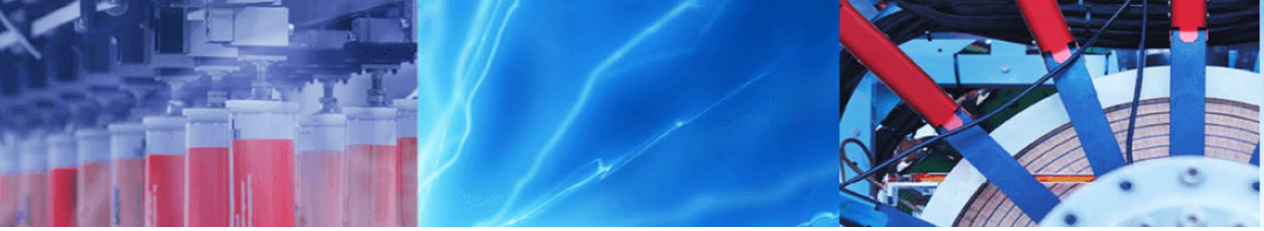

Research Article

\title{
Contamination of fee-fishing ponds with agrochemicals used in sugarcane crops
}

\author{
Maria A. da Silva Santarossa ${ }^{1}$ - Ana C. Coleone ${ }^{1} \cdot$ Nicoli P. de Mello $^{1} \cdot$ Naiara F. Ignácio $^{1} \cdot$ Angela A. Machado $^{1}$. \\ José R. Marques Silva ${ }^{2}$. Edivaldo D. Velini ${ }^{2}$ · Joaquim G. Machado Neto ${ }^{1}$
}

Received: 7 January 2020 / Accepted: 28 July 2020 / Published online: 11 August 2020

(c) Springer Nature Switzerland AG 2020

\begin{abstract}
The increasing use of agrochemicals negatively affects the environment while the generated residues impact the hydrographic networks which feed the rivers and fishing ponds, so this work investigates pesticide contamination in the supply and fishing tank waters and bottom sediment of fee-fishing ponds located in micro-basins planted with sugarcane. The results are expected to indicate the water contamination level and the impact on both the environment and human health. Therefore, water and bottom sediments from fishing ponds nearby sugarcane plantations were sampled quarterly over a year. The pesticide residues in the samples were determined by high-performance liquid chromatography coupled to mass spectrometry. The contaminants detected in the ponds were tebuthiuron $\left(2.908 \mathrm{ng} \mathrm{mL}^{-1}\right)$, metolachlor $\left(1.211 \mathrm{ng} \mathrm{mL}^{-1}\right)$, hexazinone $\left(1.065 \mathrm{ng} \mathrm{mL}^{-1}\right)$, atrazine $\left(1.008 \mathrm{ng} \mathrm{mL}^{-1}\right)$, ametryn $\left(1.004 \mathrm{ng} \mathrm{mL}^{-1}\right)$, and clomazone $\left(0.858 \mathrm{ng} \mathrm{mL}^{-1}\right)$ in the water samples while metolachlor $\left(2.308 \mathrm{ng} \mathrm{g}^{-1}\right)$, tebuthiuron $\left(0.540 \mathrm{ng} \mathrm{g}^{-1}\right)$, hexazinone $\left(0.394 \mathrm{ng} \mathrm{g}^{-1}\right)$, and isoxaflutole $\left(0.004 \mathrm{ng} \mathrm{g}^{-1}\right)$ were detected in the sediment samples. Additionally, the results show that the size of sugarcane cultivated area nearby the fishing ponds, herbicide physicochemical parameters, and applications coinciding with high rainfall are all relevant factors for water contamination. Furthermore, sediment contamination is directly correlated with the herbicides in the water ponds.
\end{abstract}

Keywords Affluent $\cdot$ Aquaculture venture $\cdot$ Fish tanks $\cdot$ Herbicides $\cdot$ Water contamination

\section{Introduction}

The population growth in recent decades, associated with the growing demand for food, has provided large dependencies on inputs, mainly phytosanitary products, such as pesticides. Data report that in Brazil, in 2013, half a million tons of pesticides were marketed and more than $90.0 \%$ of Brazilian farmers depend on the use of these pesticides [1]. In the $2014 / 2015$ harvest, $72,913.0$ tons of pesticides, composed of $82.2 \%$ of herbicides, $13.2 \%$ of insecticides, $1.90 \%$ of fungicide, and $0.01 \%$ of acaricides, were destined for sugarcane cultivation [2].
The expanding agricultural activities and the intensive use of agrochemicals cause a negative impact on the environment, affecting especially the hydrographic networks since they function as a depository for the excess agrochemicals that seep into the surrounding land and water bodies.

Although initially used to improve crop yield, the agrochemicals end up being governed by sorption (adsorption, absorption, and desorption), transformation (chemical and biological degradation), and transport (volatilization, leaching, and surface haulage) processes [3]. In some cases, less than $0.1 \%$ of the agrochemicals used

Maria A. da Silva Santarossa, mariaamaliadasilva@yahoo.com.br $\mid{ }^{1}$ Centro de Aquicultura (CAUNESP), Universidade Estadual Paulista "Júlio de Mesquita Filho" (UNESP), Via de Acesso Prof. Paulo Donato Castellane, s/n, Jaboticabal, SP CEP 14884-900, Brazil. ${ }^{2}$ Núcleo de Pesquisa Avançada Em Matologia (NUPAM), Universidade Estadual Paulista “Júlio de Mesquita Filho", Avenida Universitária, 3789, Altos do Paraíso, Botucatu, SP CEP 18610-034, Brazil. 
in agricultural areas reach the target organisms and end up in the environment and/or transported to the hydrographic network $[4,5]$. Therefore, the concern regarding water contamination with pesticides has been increasing at the same rate as the pesticide/agrochemical sales increase as well [6-8].

In the literature, Britto et al. [9], Jacomini et al. [10], Marques et al. [8], and Moreira et al. [11] investigated contamination of water bodies with pesticides and concluded that such contamination is especially caused by leaching and surface transport while the physicochemical parameters of pesticide molecules, plus meteorological conditions, relief area, and agricultural management practices influence pesticide destination.

After the organic and inorganic compounds reach the water, a significant portion remains suspended in the preexisting particulate materials, tending to deposit on the bottom, and become part of the sediments. The sediment contaminants may become available to the water column due to changing $\mathrm{pH}$, redox potential, and action of microorganisms so that the water quality is affected by the sediment due to the dynamic equilibrium processes established between water and sediment [12].

Fee-fishing ponds, where paying customers practice sport fishing (also known as recreational fishing or amateur fishing) as a hobby, are businesses that depend directly on the water quality of the hydrographic networks. In southeastern Brazil, fee-fishing ponds are mostly located in areas where sugarcane culture is intensive, and weeds are predominantly controlled by herbicides. The excess herbicide/agrochemicals used in sugarcane crops can contaminate the pond water, especially during the rainy season, and water contamination with pesticides is known to be harmful to the environment and human health as well [13-23].

Managing pond water quality requires a quantitative evaluation of the tributaries and fishponds to determine water contamination with toxic substances of agricultural origin and the risk of intoxication to the aquatic biota and human population, in order to recommend and implement mitigating actions. To this end, this work aims at determining the pesticide contamination of water from fee-fishing ponds located in areas intensively cultivated with sugarcane while correlating the pesticides in the water with the contamination of the bottom sediment of fee-fishing ponds.

The authors believe they find a contamination by herbicides in the affluent and fish tank waters of the five fee-fishing ponds analyzed, located in micro-watersheds cultivated with sugarcane. These contaminations should be higher in periods of high rainfall, due to the realization of cultivation, including the management of weeds, with the application of herbicides and consequent transport of these pesticides to the rivers. This research aims to help in the decision-making on the conditions of application of these agricultural inputs and in the adoption of the techniques of cultivation and soil conservation in the areas cultivated of the micro-basin.

\section{Materials and methods}

\subsection{Sampling}

Water and sediment samples were collected from the ponds located in areas with intense sugarcane cultivation in the northeastern (Ribeirão Preto region) and central regions of São Paulo state. Table 1 shows the pond location obtained from the IBGE topographic map, aerial photographs, and orbital images from Google Earth.

Water samples were collected from the tributaries (supply water) and from five fish tanks placed in the fee-fishing ponds while sediment samples were simultaneously collected only from the five fishtanks during one-year period to cover the rainy and dry seasons, between June/2014 and May/2015. The samples were collected against the water stream in the affluent and fish tanks, between 15.0 and $30.0 \mathrm{~cm}$ below the surface in ten distinct spots until

Table 1 Location data of the studied fee-fishing ponds

\begin{tabular}{|c|c|c|c|c|c|}
\hline $\begin{array}{l}\text { Fee- } \\
\text { fishing } \\
\text { ponds }\end{array}$ & Latitude (m) & Longitude (m) & Altitude (m) & City & Location \\
\hline A & $7,649,194,97$ & $780,932,76$ & 604 & Jaboticabal & $\begin{array}{l}\text { Cerradinho Stream or Jaboticabal Stream Sources, affluents of Cór- } \\
\text { rego Rico }\end{array}$ \\
\hline B & $7,648,476,36$ & $784,727,64$ & 581 & Jaboticabal & $\begin{array}{l}\text { Cerradinho Stream or Jaboticabal Stream Sources, affluents of Cór- } \\
\text { rego Rico }\end{array}$ \\
\hline $\mathrm{C}$ & $7,659,327,13$ & $806,343,56$ & 573 & Sertãozinho & $\begin{array}{l}\text { Near the Vendinha Stream source, affluent of the Ribeirão do Sul or } \\
\text { Sertãozinho Stream }\end{array}$ \\
\hline $\mathrm{D}$ & $7,631,466,79$ & $774,507,62$ & 632 & Santa Ernestina & Coco Stream affluent \\
\hline$E$ & $7,640,075,87$ & $789,601,72$ & 642 & Jaboticabal & Near the Inhaúma Stream or Santa Miquelina \\
\hline
\end{tabular}


filling up the sampling collector. Subsequently, the water samples were placed in a graduated polypropylene bucket $[24,25]$, homogenized, and transferred to $1.0-\mathrm{L}$ plastic flasks coated with aluminum foil $[24,25]$, to form a composite sample.

The bottom sediment samples were collected using a 10.0-cm-long hopper with $3.81 \mathrm{~cm}$ diameter [25] from ten different spots at depths varying between 0.0 and $10.0 \mathrm{~cm}$, transferred to plastic bags, and homogenized. Part of the bottom sediment samples was sent to the Laboratory of Soil Management and Conservation of the FCAV/UNESP, in Jaboticabal, to determine the physicochemical parameters following the procedures of ABNT NBR 7181 [26] and the Handbook of Soil Analysis Methods [27].

The water and remainder sediment samples were sent to the Laboratory of Agrochemical Ecotoxicology and Occupational Health, FCAV/UNESP, in Jaboticabal, and stored in freezers at $-20^{\circ} \mathrm{C}$ [24-28].

\subsection{Sample preparation}

For detecting the pesticides, the water samples were thawed at room temperature, shaken manually, and filtered. Aliquots of $40.0 \mathrm{~mL}$ were filtered on a $47.0-\mathrm{mm}$ glass fiber membrane with $0.45 \mu \mathrm{m}$ porosity using a vacuum pump, and the filtrate was kept in plastic bottles until further analysis.

Subsequently, the filtered samples were eluted in a $C_{18}$ cartridge following the steps of the procedure by Kouzayha et al. [29]: conditioning of the $C_{18}$ column with methanol and deionized water, elution of the samples/sorption of the analytes in the adsorbent, elution of the analytes trapped in the adsorbent with methanol $(2.5 \mathrm{~mL})$, and further concentration of the compound of interest. The concentrated samples were filtered in Millex HV syringe filters (Millipore) with Durapore ${ }^{\circledR}$ membrane, $0.45 \mu \mathrm{m}$ pore size and $13.0 \mathrm{~mm}$ diameter, and stored in amber vials (Flow Supply) for further quantification of the compounds.

The recovery test of the sample concentration procedure used the $0.1 \mathrm{ng} \mathrm{mL}^{-1}$ concentration for recovery coefficient values varying between $72.3 \%$ and $98.8 \%$ with 1.2 and 6.9 standard deviations (SD), respectively. The recovery percentage between 70.0 and $120.0 \%$ and $S D<10.0 \%$ [30] was used as the ideal parameters.

Subsamples of approximately $25.0 \mathrm{~mL}$ were collected from the moist sediment samples, filled into $50.0 \mathrm{~mL}$ Falcon tubes, frozen at $-80^{\circ} \mathrm{C}$, and lyophilized for $48 \mathrm{~h}$. After lyophilization, 7.0-g samples were transferred to plastic cartridges with a porous membrane and a small compartment to collect the sediment solution, followed by addition of $3.0 \mathrm{~mL}$ deionized water and left still for $24 \mathrm{~h}$. After that, the cartridges were centrifuged at $4000.0 \mathrm{rpm}$, $25^{\circ} \mathrm{C}$ for $10.0 \mathrm{~min}$ [31]; the supernatant was collected and filtered with Millex HV syringe filters (Millipore) with Durapore $^{\circledast}$ membrane, $0.45 \mu \mathrm{m}$ pore size and $13.0 \mathrm{~mm}$ diameter. The filtrate was stored in amber (Flow Supply) vials for further chemical analysis.

The HPLC coupled to mass spectrometry analyses to determine the pesticides in the water and sediment samples was performed at the Center for Advanced Research on Weed Control (NUPAM) of the College of Agronomy FCA/UNESP, in Botucatu, SP. The chromatographic method was validated according to the parameters recommended by Ribani et al. [32].

The pesticide analysis was conducted using a

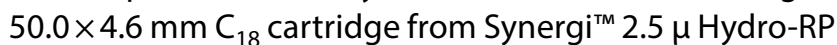
$100.0 \AA$, with $0.4 \mathrm{~mL} \mathrm{~min}{ }^{-1}$ flow rate and $30.0 \mu \mathrm{L}$ injection volume. The compounds were separated using the gradient elution system, starting with the methanol and water mixture plus $0.5 \%$ acetic acid. The solvent ratio started at 20:80 (methanol: water), reached 95:5 after $8 \mathrm{~min}$, stabilized for $12.0 \mathrm{~min}$, and returned to the initial ratio at $15.0 \mathrm{~min}$, for a $19.0 \mathrm{~min}$ total run time.

The analytical curves of the analyzed products were built from standard solution concentrations (purity above $99.8 \%$ ) of $0.39 ; 0.78 ; 1.56 ; 3.13 ; 6.25 ; 12.5 ; 25.0 ; 50.0$; and $100.0 \mathrm{ng} \mathrm{mL}^{-1}$, using analytical grade reagents and deionized water (18.8 $\mathrm{M} \Omega$ ).

The analysis results of the water samples using the pesticide standard solution indicated detection limits varying from 0.0098 to $0.0783 \mathrm{ng} \mathrm{mL}^{-1}$, quantification limits from 0.0293 to $0.2347 \mathrm{ng} \mathrm{mL}^{-1}$, and determination coefficients from 0.9894 to 0.9980 . For the bottom sediments, the detection limits varied between 0.0978 and $3.1300 \mathrm{ng} \mathrm{mL}^{-1}$, quantification limits from 0.2932 and $9.3900 \mathrm{ng} \mathrm{mL}^{-1}$, and determination coefficients from 0.9883 to 0.9992 .

The multiresidue method used for the chemical analysis allowed to quantify efficiently the following herbicides ametryn (N2-ethyl-N4-isopropyl-6-methylthio-1,3,5triazine-2,4-diamine; CAS 834-12-8), atrazine (6-chloroN2-ethyl-N4-isopropyl-1,3,5-triazine-2,4-diamine; CAS 1912-24-9), clomazone (2-(2-chlorobenzyl)-4,4-dimethyl1,2-oxazolidin-3-one; CAS 81777-89-1), diclosulan (N-(2,6dichlorophenyl)-5-ethoxy-7-fluoro-[1,2,4]triazolo[1,5-c] pyrimidine-2-sulfonamide; CAS 145701-21-9), hexazinone (3-cyclohexyl-6-dimethylamino-1-methyl-1,3,5-triazine2,4(1H,3H)-dione; CAS 51235-04-2), isoxaflutole (5-cyclopropyl-1,2-oxazol-4-yl)(a,a,a-trifluoro-2-mesyl-p-tolyl) methanone; CAS 141112-29-0) and its metabolite diketonitrile (DKN) (2-(cyclopropanecarbonyl)-3-[2-methylsulfonyl-4-(trifluoromethyl)phenyl]-3-oxopropanenitrile), metolachlor (2-chloro- $N$-(6-ethyl-o-tolyl)- $N$-[(1RS)-2-methoxy-1-methylethyl]acetamide; CAS 51218-45-2), pendimethalin (3,4-dimethyl-2,6-dinitro-N-pentan-3-ylaniline; 
CAS 40487-42-1), sulfentrazone ( $\mathrm{N}$-[2,4-dichloro-5-[4(difluoromethyl)-3-methyl-5-oxo-1,2,4-triazol-1-yl]phenyl]methanesulfonamide; CAS 122836-35-5), sulfometuron (2-[(4,6-dimethylpyrimidin-2-yl)carbamoylsulfamoyl] benzoic acid; CAS 74222-97-2) and tebuthiuron ( $N$-[5-(1,1dimethylethyl)-1,3,4-thiadiazol-2-yl]-N,N'-dimethylurea; CAS 34014-18-1) and the insecticides, carbofuran ([2,2-dimethyl-3H-1-benzofuran-7-yl] N-methylcarbamate; CAS 1563-66-2), fipronil (5-amino-1-[2,6-dichloro4-(trifluoromethyl)phenyl]-4-(trifluoromethylsulfinyl) pyrazole-3-carbonitrile; CAS 120068-37-3) and malathion (diethyl 2-dimethoxyphosphinothioylsulfanylbutanedioate; CAS 121-75-5).

\subsection{Risk of environmental poisoning of the herbicide tebuthiuron for Oreochromis niloticus and Lemna minor}

The risk assessment for the organisms Oreochromis niloticus and Lemna minor was performed with the herbicide tebuthiuron, as this proved to be prevalent in water samples from fee-fishing ponds. The calculation of the risk of environmental poisoning was based on the relationship between the estimated environmental concentration (EEC) and the toxicity values for $O$. niloticus and $L$. minor. Toxicity values were found from acute toxicity tests performed in the laboratory by the authors.

The procedures used in ecotoxicological tests were established in OECD 221 [33] standards for L. minor and ABNT NBR 15499 [34] for O. niloticus. For O. niloticus, after a $48 \mathrm{~h}$ exposure with the herbicide tebuthiuron at concentrations 20.0; 22.0; 24.0; 26.0 and $28.0 \mathrm{mg} \mathrm{L}^{-1}$ (concentrations defined from preliminary tests), in a controlled temperature room with a photoperiod of $16 \mathrm{~h}$ and a temperature of $24{ }^{\circ} \mathrm{C} \pm 2$, the mortality of organisms in the experimental units was assessed and using the statistical method Trimmed Spearman-Karber [35], median lethal concentrations were calculated $\mathrm{CL}_{50-48} \mathrm{~h}$, and the safety range was described by the upper and lower limit (LI and $\mathrm{LS}, p=0.05)$.

For L. minor, the exposure period was 07 days at concentrations $0.01 ; 0.02 ; 0.05 ; 0.1 ; 0.2 ; 0.3 ; 0.5 ;$ and $1.0 \mathrm{mg} \mathrm{L}^{-1}$ of the herbicide, in static system, with a 16-h photoperiod, luminosity between 6,500.0 and 10,000.0 Ix, and a temperature of $24 \pm 2{ }^{\circ} \mathrm{C}$. In the $3 \mathrm{rd}, 5$ th, and 7 th days of exposure, the evaluation of inhibition of growth of the test organisms was performed by counting the number of live fronds. With frond number values formed at tested concentrations, median inhibitory concentration values were calculated $\left(\mathrm{Cl}_{50-7 \mathrm{~d}}\right)$ and the safety range was described by the upper and lower limits (LI and LS, $p=0.05$ ) using the statistical method Trimmed Spearman-Karber [35].
The value of $\mathrm{CL}_{50-48 \mathrm{~h}}$ was $22.67 \mathrm{mg} \mathrm{L}^{-1}$, with $\mathrm{LI}$ of $21.42 \mathrm{mg} \mathrm{L}^{-1}$ and LS of $24.01 \mathrm{mg} \mathrm{L}^{-1}$ and $\mathrm{Cl}_{50-7 \mathrm{~d}}$ of $0.06 \mathrm{mg} \mathrm{L}^{-1}$, with LI of $0.05 \mathrm{mg} \mathrm{L}^{-1}$ and LS of $0.06 \mathrm{mg} \mathrm{L}^{-1}$.

The EEC values were calculated using the computational model GENEEC, considering the contamination of a mirror of water of 1.0 ha per surface runoff with $100.0 \%$, $50.0 \%, 25.0 \%, 12.5 \%, 6.25 \%, 3.12 \%$, and $1.56 \%$ of the highest recommended dose of the herbicide tebuthiuron for sugarcane culture $\left(1200.0 \mathrm{~g} \mathrm{ha}^{-1}\right)$ as per the package leaflet of the Commercial Formulation Combine $500 \mathrm{SC}^{\circledR}$.

In the calculation of the EEC values was also considered the uniform distribution of tebuthiuron in the whole volume of water from the one hectare water mirror $(10,000.0$ $\mathrm{m}^{2}$ ) [36] with depths of $0.30 ; 1.0$ and $2.0 \mathrm{~m}$ [36-39]. The mean density of the water considered in the calculations was $1.0 \mathrm{~g} \mathrm{~cm}^{-3}$.

The justification for the calculations at $0.3 \mathrm{~m}$ depth is because this is the range where zooplankton and phytoplankton are found, which are organisms at the base of the food chain. For depths 1.0 and $2.0 \mathrm{~m}$, it is because they are recommended by the EPA for risk assessment in aquatic environments. After the calculation of the EEC, the risk quotient $(\mathrm{RQ})$ was determined, as described by Goktepe et al. [40].

\subsection{Statistical analysis}

Minitab software version 16 was used for the statistical analysis. Water and sediment samples were analyzed in triplicate. The analyzed variation sources were discrete (fee-fishing ponds, sampling sites, dry and rainy seasons) and continuous (contamination) data. The means of two parameters were compared by the T-Test while means of several parameters by the one-way ANOVA. To verify the relationship between the average slope of the reliefs of the watersheds in which the fee-fishes are inserted, the area of riparian forest surrounding the river network of the micro-basins, the areas of sugarcane plantations, and the contamination of the waters of the fee-fishing ponds, the data were analyzed by the Pearson correlation coefficient $(p=0.05)$.

\section{Results and discussion}

The results showed that the water samples of all five feefishing ponds were contaminated with the following residual pesticides ametryn, atrazine, clomazone, hexazinone, metolachlor, and tebuthiuron (Table 2), usually used in sugarcane crops. The contamination levels in the evaluated year, from the highest to the lowest, were as follows: tebuthiuron $\left(2.908 \mathrm{ng} \mathrm{mL}^{-1}\right),(P$-value $=0.000)$, followed by metolachlor $\left(1.211 \mathrm{ng} \mathrm{mL}^{-1}\right)$, hexazinone $\left(1.065 \mathrm{ng} \mathrm{mL}^{-1}\right)$, 


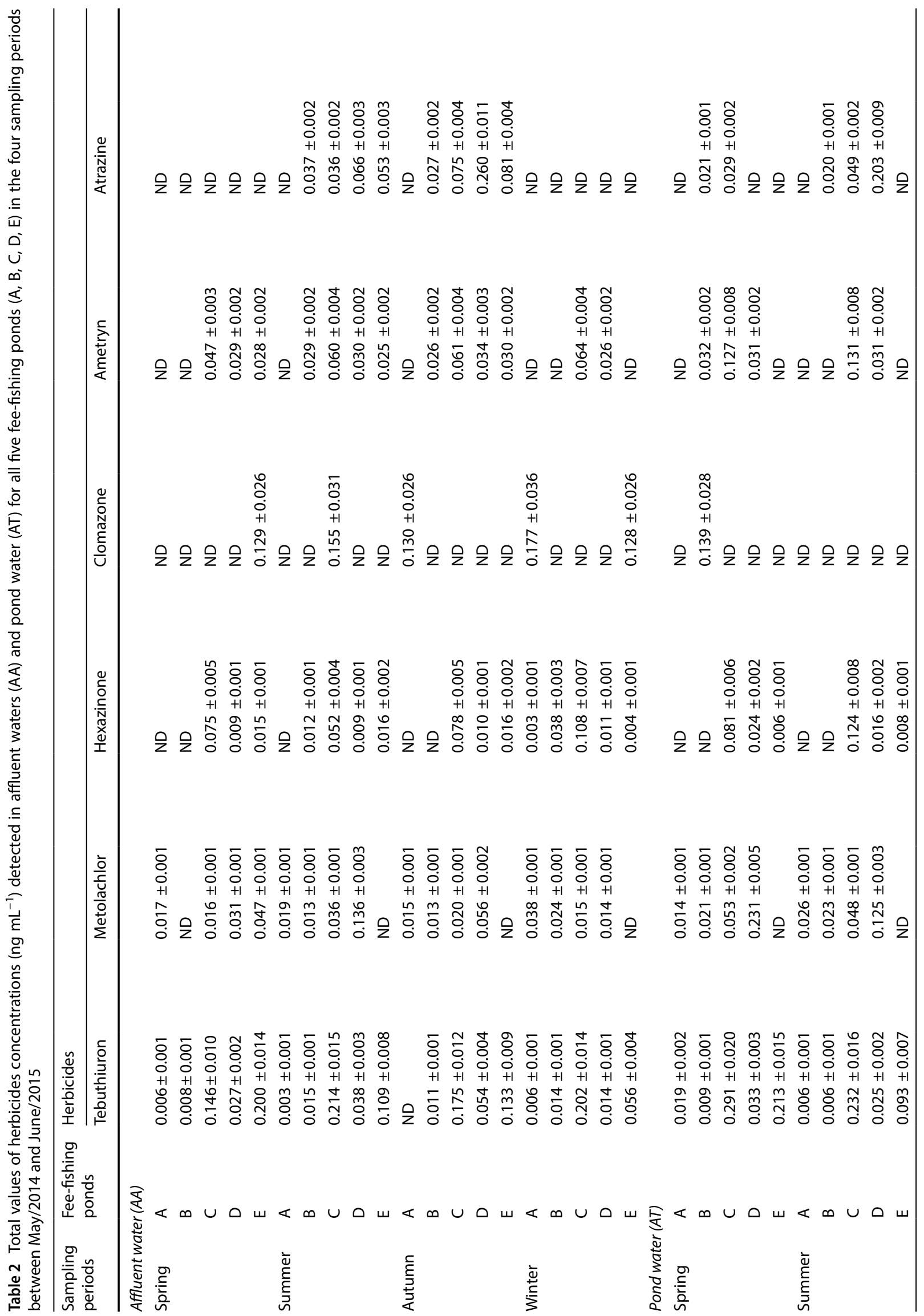




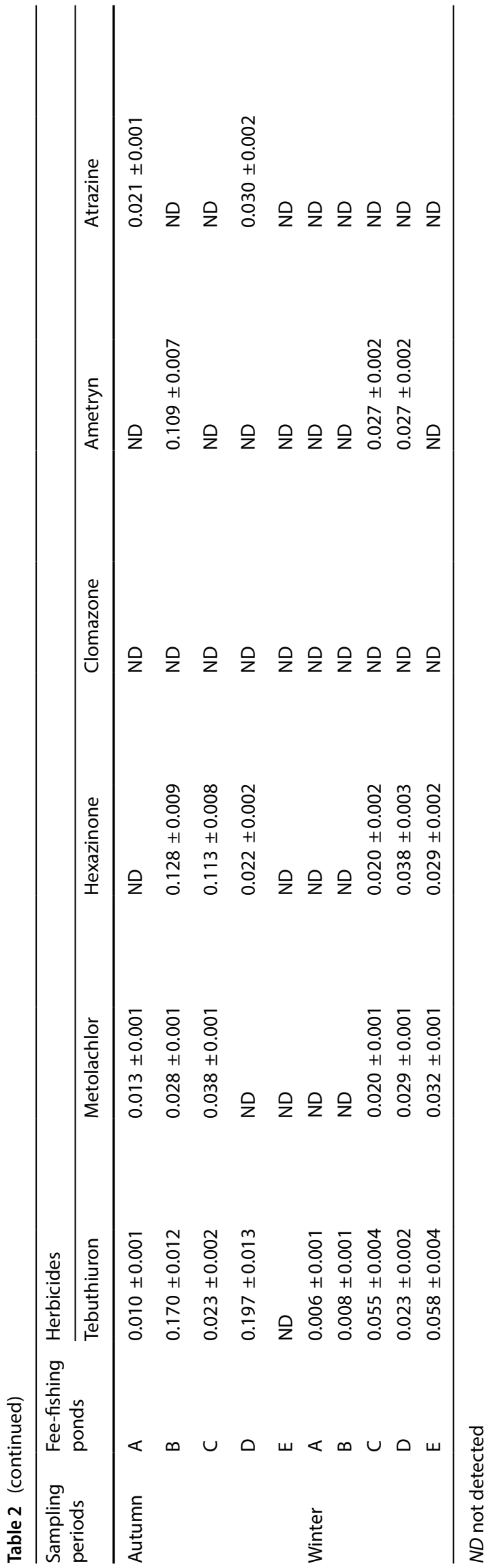

atrazine $\left(1.008 \mathrm{ng} \mathrm{mL}^{-1}\right)$, ametryn $\left(1.004 \mathrm{ng} \mathrm{mL}^{-1}\right)$, and clomazone (0.858 $\mathrm{ng} \mathrm{mL}^{-1}$ ) (Table 2 ).

It is worth noting that the portion of the agrochemicals applied to crops that do not reach the target organisms become available and susceptible to transport to surrounding soil and water bodies $[4,5]$. Even at low concentrations, agrochemicals transported from terrestrial to aquatic ecosystems may pose risks to several species since they accumulate on tissues and organs of exposed organisms while the toxic effects are transferred through the food chain to other organisms, such as humans, in a process called biomagnification [41].

Pesticides can negatively impact non-target organisms, and among them, fish and humans can be affected. In a broad literature review, Rohr and Mccoy [23] reported that fish exposed to the herbicide atrazine had decreasing growth rate, diminishing predatory behavior, high locomotor activity, and reduced immunity, accompanied by high infection rates. The authors also report morphological abnormalities of the gonads associated with changes in the production of sex hormones, showing that atrazine can disrupt the endocrine system.

Almeida et al. [42] observed estrogenic and anti-androgenic effects with altered in spermatogenesis and in the size of the gonads on Oreochromis niloticus exposed to tebuthiuron in concentrations of approximately 1.5 times lower than the highest concentration detected in the searchers of this survey.

Botelho et al. [43] observed that ametryn was more genotoxic to $D$. rerio since it induced higher incidence of nuclear abnormalities in erythrocytes compared to atrazine when exposed Danio rerio the concentrations of atrazine and ametryn approximately 6 and 8 times higher than the higher concentrations found in the fee-fishing ponds of the present study, respectively.

A histological study in Rhamdia quelen showed a vacuolization in the liver and a decrease in the acetylcholinesterase activity in the brain and muscle after exposure by clomazone [44]. For the same exposure conditions, Crestani et al. [45] observed changes in protein and carbohydrate metabolism after Rhamdia quelen exposure to clomazone.

Nieves-Puigdoller et al. [46] exposed Atlantic salmon juveniles to the $100.0 \mathrm{ng} \mathrm{mL}^{-1}$ hexazinone and 10.0 and $100.0 \mathrm{ng} \mathrm{mL}^{-1}$ atrazine concentrations for 21 days and observed that, under the imposed conditions, hexazinone did not affect tolerance of organisms to salinity, but exposure to atrazine caused a disturbance in ion regulation, growth, and endocrine conditions of exposed organisms.

The effects of metolachlor AO (a metabolite of the herbicide metolachlor and s-metolachlor) on the life early stages of Procambarus virginalis were evaluated based on the mortality, growth, ontogenetic development, 
behavior, oxidative stress, antioxidant biomarkers, and histopathology results. The authors observed that chronic exposure to concentrations of the metabolite of approximately 18.0, 181.0, and 1818.0 times greater than the highest concentration detected in the present study reduced growth, ontogenetic development, and antioxidant system. In addition, the exposure also caused pathological changes in the hepatopancreas and gills in the life early stages [47]. Velisek et al. [48] found similar results for Procambarus virginalis exposed to s-metolachlor concentrations approximately $8.0,48.0$, and 476.0 times higher than the highest concentration detected in the waters of the fee-fishing ponds.

Based on this study results and the data available in the literature, the atrazine, ametryn, hexazinone, clomazone, and metolachlor concentrations found in the supply water and fish tank water during the period (Table 8) should not cause damage to the aquatic biota.

For the herbicide tebuthiuron, through the results of the risk assessment for $O$. niloticus, it can be observed that the herbicide qualifies as low risk of environmental poisoning, regardless of dose (dilution of $E E C$ ) and depth, as all $R Q$ values are less than 0.05 (Table 3, 4 and 5). As the concentrations of tebuthiuron found in fee-fishing ponds waters are lower than the values of acute toxicity concentrations, tebuthiuron offers low risk of environmental poisoning for O. niloticus.

On the other hand, for aquatic macrophyte L. minor, tebuthiuron was classified as high to medium risk of environmental poisoning and for scenarios with dilutions of $3.12 \%$ and $1.56 \%$ at a depth of $2.0 \mathrm{~m}$, and at a depth of $6.25 \%, 3.12 \%$, and $1.56 \%$ at a depth of $3.0 \mathrm{~m}$ was classified as low risk of environmental poisoning.

According to Pinheiro et al. [49], there is an inverse relationship between the depth of a body of water and the amount of aquatic macrophytes present in the environment. Given this information, in addition to L. minor being a floating species, it can be expected that the amount of

Table 3 Risk quotient values (RQ) and their respective risk classifications for the herbicide tebuthiuron for organisms $L$. minor and $O$. niloticus at a depth of $0.30 \mathrm{~m}$

\begin{tabular}{lll}
\hline Dilution of EEC & Species & \\
\hline & L. minor & O. niloticus \\
$100 \%\left(0.40 \mathrm{mg} \mathrm{L}^{-1}\right)$ & 6.67 High risk & 0.0176 Low risk \\
$50 \%\left(0.20 \mathrm{mg} \mathrm{L}^{-1}\right)$ & 3.33 High risk & 0.0088 Low risk \\
$25 \%\left(0.10 \mathrm{mg} \mathrm{L}^{-1}\right)$ & 1.67 High risk & 0.0044 Low risk \\
$12.5 \%\left(0.05 \mathrm{mg} \mathrm{L}^{-1}\right)$ & 0.83 High risk & 0.0022 Low risk \\
$6.25 \%\left(0.025 \mathrm{mg} \mathrm{L}^{-1}\right)$ & 0.42 Medium risk & 0.0011 Low risk \\
$3.12 \%\left(0.012 \mathrm{mg} \mathrm{L}^{-1}\right)$ & 0.21 Medium risk & 0.0005 Low risk \\
$1.56 \%\left(0.006 \mathrm{mg} \mathrm{L}^{-1}\right)$ & 0.10 Medium risk & 0.0003 Low risk \\
\hline
\end{tabular}

aquatic macrophyte is higher at a depth of $0.3 \mathrm{~m}$, scenario in which the herbicide was classified as high to medium risk of environmental poisoning for this species.

One of the effects of the rapid decrease in macrophyte biomass in the aquatic system may be the deprivation of oxygen to fish and other organisms, as well as changes in habitat, which will be short of food and shelter $[38,50]$.

In view of the results, the risks of environmental poisoning from tebuthiuron to $L$. minor may characterize an alert as to the possibility of environmental health impairment of watersheds occupied by sugarcane cultivation.

Cronic human exposure to pesticides via ingestion of contaminated food and water may trigger several health problems as increasing rates of cancers, such as prostate, lung, colorectal, pancreas, ovaries, testicles, skin (melanoma), blood (leukemia), lymphatic system (non-Hodgkin's lymphoma), and breast [14, 15, 18, 19]. There are also scientific reports on the increased number of spontaneous abortions, preterm births after prenatal exposure, reduced pregnancy time, $[13,17,21]$, and autism cases in children [22] born to women who are constantly exposed to pesticides.

Table 4 Risk quotient values (RQ) and their respective risk classifications for the herbicide tebuthiuron for organisms $L$. minor and $O$. niloticus at a depth of $2.0 \mathrm{~m}$

\begin{tabular}{lll}
\hline & \multicolumn{2}{l}{ Species } \\
\cline { 2 - 3 } Dilution of EEC & L. minor & O. niloticus \\
\hline $100 \%\left(0.06 \mathrm{mg} \mathrm{L}^{-1}\right)$ & 1.00 High risk & 0.0026 Low risk \\
$50 \%\left(0.03 \mathrm{mg} \mathrm{L}^{-1}\right)$ & 0.50 Medium Risk & 0.0013 Low risk \\
$25 \%\left(0.015 \mathrm{mg} \mathrm{L}^{-1}\right)$ & 0.25 Medium Risk & 0.0006 Low risk \\
$12.5 \%\left(0.0075 \mathrm{mg} \mathrm{L}^{-1}\right)$ & 0.12 Medium Risk & 0.0003 Low risk \\
$6.25 \%\left(0.0037 \mathrm{mg} \mathrm{L}^{-1}\right)$ & 0.06 Medium Risk & 0.0002 Low risk \\
$\left.3.12 \% 0.0019 \mathrm{mg} \mathrm{L}^{-1}\right)$ & 0.03 Low risk & 0.00008 Low risk \\
$1.56 \%\left(0.0009 \mathrm{mg} \mathrm{L}^{-1}\right)$ & 0.01 Low risk & 0.00004 Low risk \\
\hline
\end{tabular}

Table 5 Risk quotient values (RQ) and their respective risk classifications for the herbicide tebuthiuron for organisms $L$. minor and $O$. niloticus at a depth of $3.0 \mathrm{~m}$

\begin{tabular}{lll}
\hline Dilution of EEC & \multicolumn{2}{l}{ Species } \\
\cline { 2 - 3 } & L. minor & O. niloticus \\
\hline $100 \%\left(0.04 \mathrm{mg} \mathrm{L}^{-1}\right)$ & 0.67 High risk & 0.0018 Low risk \\
$50 \%\left(0.02 \mathrm{mg} \mathrm{L}^{-1}\right)$ & 0.33 Medium risk & 0.0009 Low risk \\
$25 \%\left(0.01 \mathrm{mg} \mathrm{L}^{-1}\right)$ & 0.17 Medium risk & 0.0004 Low risk \\
$12.5 \%\left(0.005 \mathrm{mg} \mathrm{L}^{-1}\right)$ & 0.08 Medium risk & 0.0002 Low risk \\
$6.25 \%\left(0.0025 \mathrm{mg} \mathrm{L}^{-1}\right)$ & 0.04 Low risk & 0.0001 Low risk \\
$3.12 \%\left(0.0012 \mathrm{mg} \mathrm{L}^{-1}\right)$ & 0.02 Low risk & 0.00006 Low risk \\
$1.56 \%\left(0.0006 \mathrm{mg} \mathrm{L}^{-1}\right)$ & 0.01 Low risk & 0.00003 Low risk \\
\hline
\end{tabular}


The high mobility of pesticides that allow easy transport from the application site to large water bodies is highly correlated with the physicochemical parameters of each molecule, and this study shows that these characteristics of the herbicides intensified the transport via surface runoff and leaching, increasing the water contamination potential of these molecules, as shown in Table 6 , since the herbicides found present a variation in Koc between 80 and 316 , classifying them as mobile to moderately mobile [51].

Studies have confirmed that the intense use of pesticides in crops, associated with the molecule physicochemical characteristics, has impacted negatively the hydrographic networks [52-56]. These researches corroborate with the results found, because the solubility values of the detected herbicides range between 35 and $33.000 \mathrm{mg} \mathrm{L}^{-1}$ (Table 6), classifying them as low to high solubility, with the exception of ametryn and atrazine, classified as moderate to low solubility which is related to the lower concentrations of these herbicides in the evaluated fee-fishing ponds samples [51].

The highest herbicide concentrations in the water samples were determined in the periods with high precipitations ( $P$ value $=0.037$ ) (Table 7$)$ coinciding, in the studied region, with the soil preparation for the crops, such as applying herbicide to manage weeds during the rainy season [57]. As the precipitation starts, the used agrochemicals are easily transported to the local river network via surface runoff or percolation toward surface and groundwater [9], causing higher water contamination during the rainy season.

Contrary to the other herbicides, the clomazone concentration was higher in the dry season compared to the rainy season (Table 7). This result is explained by the fact that clomazone application is recommended during the low precipitation period due to the physicochemical characteristics of clomazone that desorbs into the soil solution becoming available for absorption by the seedling roots and/or caulicles even in low soil moisture [57-59].

When it is intended to understand the contamination of water bodies, some factors should be considered as: slope of the land, the presence of riparian forest, and the area of plantations located near the water courses (Table 8).

Of the five fee-fishing ponds evaluated, pond $C$ had the highest herbicide concentration $\left(3.096 \mathrm{ng} \mathrm{mL}^{-1}\right)(P$ value $=0.000$ ) (Table 9) and, coincidentally, the largest sugarcane planted area (96.84\%) nearby the basin and the fishing pond (Table 8). By the $r$ values calculated of

Table 6 Chemical characteristics of herbicides found in fee-fishing ponds samples [51]

\begin{tabular}{|c|c|c|c|c|c|c|}
\hline \multirow[t]{2}{*}{ Chemical characteristics } & \multicolumn{6}{|l|}{ Herbicides } \\
\hline & Tebuthiuron & Metolachlor & Hexazinone & Clomazone & Ametryn & Atrazine \\
\hline $\begin{array}{l}\text { Solubility-In water at } 20^{\circ} \mathrm{C} \\
\left(\mathrm{mg} \mathrm{L}^{-1}\right)\end{array}$ & 2500-High & 530-High & 33,000-High & 1212-High & 200-Moderate & 35-Low \\
\hline $\begin{array}{l}\text { Potential for particle bound } \\
\text { transport index }\end{array}$ & Medium & Medium & Medium & Low & Medium & Medium \\
\hline Koc & 80-Moderately mobile & $\begin{array}{l}\text { 120-Mod- } \\
\text { erately } \\
\text { mobile }\end{array}$ & 54-Mobile & $\begin{array}{l}\text { 300-Mod- } \\
\text { erately } \\
\text { mobile }\end{array}$ & 316-Moderately mobile & $\begin{array}{l}\text { 100- } \\
\text { Mod- } \\
\text { erately } \\
\text { mobile }\end{array}$ \\
\hline $\begin{array}{l}\text { Values found in the samples } \\
\left(\mathrm{mg} \mathrm{L}^{-1}\right)\end{array}$ & $2.91 \mathrm{E}-03$ & $1.21 \mathrm{E}-03$ & $1.07 \mathrm{E}-03$ & $8.58 \mathrm{E}-04$ & $1.00 \mathrm{E}-03$ & $1.01 \mathrm{E}-03$ \\
\hline
\end{tabular}

Table 7 Sum of herbicides concentration values $\left(\mathrm{ng} \mathrm{mL}^{-1}\right)$ detected in the collected waters and rainfall (mm), during the sampling period from June/2014 to May/2015, grouped in drought and rainy seasons

\begin{tabular}{|c|c|c|c|c|c|c|c|c|}
\hline \multirow[t]{2}{*}{ Sampling period } & \multirow[t]{2}{*}{ Rainfall (mm) } & \multicolumn{6}{|l|}{ Herbicides } & \multirow[b]{2}{*}{ Total } \\
\hline & & Tebuthiuron & Metolachlor & Hexazinone & Clomazone & Ametryn & Atrazine & \\
\hline \multicolumn{9}{|l|}{ Affluent water $(A A)$} \\
\hline Dry & 308.52 & 0.679 & 0.202 & 0.263 & 0.434 & 0.194 & ND & 1.772 \\
\hline Rainy & 899.54 & 0.752 & 0.308 & 0.193 & 0.285 & 0.295 & 0.635 & 2.468 \\
\hline \multicolumn{9}{|l|}{ Pond water (AT) } \\
\hline Dry & 308.52 & 0.715 & 0.400 & 0.198 & 0.139 & 0.244 & 0.050 & 1.746 \\
\hline Rainy & 899.54 & 0.762 & 0.301 & 0.411 & ND & 0.271 & 0.323 & 2.068 \\
\hline
\end{tabular}

ND not detected 
Table 8 Percentages of the average slope of the micro-basin in which the fee-fishing ponds are inserted $A, B, C, D$ and $E$, of the riparian forest around the course of the river that supplies them, of the area of the micro-watersheds planted with sugar cane and the $\%$ contamination of their water by herbicides

\begin{tabular}{llllll}
\hline & A & B & C & D & E \\
\hline Medium declivity (\%) & 1.91 & 0.48 & 1.45 & 0.30 & 1.24 \\
Riparian forest area (\%) & 3.64 & 5.24 & 3.16 & 9.27 & 9.43 \\
Plantation area (\%) & 96.36 & 56.35 & 96.84 & 90.73 & 90.57 \\
\% of water contamination & 6.57 & 12.18 & 38.44 & 24.07 & 18.73 \\
Pearson's correlation test $(a=5 \%):$ & & & & \\
Declivity $\times$ Contamination: $r=0.0911^{\mathrm{ns}}$ & & & \\
Riparian forest $\times$ Contamination: $r=-0.0390^{\mathrm{ns}}$ & & \\
Plantation Area $\times$ Contamination: $r=0.3690^{\mathrm{ns}}$ & & \\
\hline
\end{tabular}

$n s$ not significant $(p \geq 0.05)$

the Pearson correlation test (Table 8), there is an insignificant correlation, according to the classifications of Hinkle et al. [60] between the contamination of the waters of the fee-fishing ponds by the herbicides with the average slope of the micro-basins $(r=0.0911)$ and with the riparian forest area around the local hydrographic network $(r=-0.0390)$.

The non-existent relationship can be related to the flat land cultivated with the cultivation of sugar cane in the micro-basins of the fee-fishing ponds. The slopes of the reliefs of fee-fishing ponds micro-watersheds are between 0.30 and $1.91 \%$ and are classified as flat relief, according to the slope classes adopted in the Brazilian soil classification system [61]. The correlation between the contamination of the fee-fishing ponds waters with herbicides and the percentage of the area of the micro-watersheds planted with sugar cane $(r=0.3690)$ was positive, but low and classified as meaningless [60].

Therefore, the amount and number of agrochemicals applied to the sugarcane plantations and soil management were probably the local environmental factors influencing pond water contamination.

The lower herbicide contamination in the fish tank waters, except for $B$ and $D$ fishing ponds, compared to the tributaries (Table 9), is probably associated with several different processes governing the transport of agrochemicals in the water [62], emphasizing processes such as the adsorption of the pesticide molecules to the suspended sediment, as well as biodegradation and bioaccumulation by the aquatic organisms in the tanks.

The sediment samples had the following herbicides: metolachlor $\left(2.308 \mathrm{ng} \mathrm{g}^{-1}\right)(\mathrm{P}$-value $=0.005)$, tebuthiuron $\left(0.540 \mathrm{ng} \mathrm{g}^{-1}\right)$, hexazinone $\left(0.394 \mathrm{ng} \mathrm{g}^{-1}\right)$, and isoxaflutole $\left(0.004 \mathrm{ng} \mathrm{g}^{-1}\right)$. Therefore, the herbicides found contaminating the fishtank waters were also observed in the bottom sediments, except for isoxaflutole, which was found only in the sediment matrix ( $P$ value $=0.691$, rejected the hypothesis of different means). The highest herbicide concentrations were observed in the sediments of pond $C$ $\left(1.114 \mathrm{ng} \mathrm{g}^{-1}\right)$ followed by $A\left(1.096 \mathrm{ng} \mathrm{g}^{-1}\right)$ and the lowest in the sediments of ponds $D\left(0.503 \mathrm{ng} \mathrm{g}^{-1}\right)$, followed by $B$ $\left(0.446 \mathrm{ng} \mathrm{g}^{-1}\right)$, and $\mathrm{E}\left(0.087 \mathrm{ng} \mathrm{g}^{-1}\right)$. Among the evaluated ponds, the average contamination of sediment and water samples was similar $(P$ value $=0.691)$.

The sediment physical composition has a relevant contribution to the adsorption capacity. Studies have shown that clay minerals contribute to soil sorption due to their physicochemical characteristics [63-65], corroborating our results since the highest herbicide concentrations

Table 9 Sum of values of herbicide concentrations $\left(n \mathrm{~g} \mathrm{~mL}^{-1}\right)$ in affluent (AA) and tank (AT) waters for the five fee-fishing ponds (A, B, C, D e E), in the period between June 2014 and May 2015

\begin{tabular}{|c|c|c|c|c|c|c|c|c|}
\hline \multirow[t]{2}{*}{ Fee-fishing ponds } & \multirow[t]{2}{*}{ Sampling site } & \multicolumn{6}{|l|}{ Herbicides } & \multirow[t]{2}{*}{ Total } \\
\hline & & Tebuthiuron & Metolachlor & Hexazinone & Clomazone & Ametryn & Atrazine & \\
\hline \multirow[t]{2}{*}{$A$} & $\mathrm{AA}$ & 0.015 & 0.089 & 0.003 & 0.307 & ND & ND & 0.414 \\
\hline & AT & 0.041 & 0.053 & ND & ND & ND & 0.021 & 0.115 \\
\hline \multirow[t]{2}{*}{ B } & AA & 0.048 & 0.050 & 0.050 & ND & 0.055 & 0.064 & 0.267 \\
\hline & AT & 0.193 & 0.072 & 0.128 & 0.139 & 0.141 & 0.041 & 0.714 \\
\hline \multirow[t]{2}{*}{ C } & $\mathrm{AA}$ & 0.737 & 0.087 & 0.313 & 0.155 & 0.232 & 0.111 & 1.635 \\
\hline & AT & 0.601 & 0.159 & 0.338 & ND & 0.285 & 0.078 & 1.461 \\
\hline \multirow[t]{2}{*}{ D } & AA & 0.133 & 0.237 & 0.039 & ND & 0.119 & 0.326 & 0.854 \\
\hline & AT & 0.278 & 0.385 & 0.100 & ND & 0.089 & 0.233 & 1.085 \\
\hline \multirow[t]{2}{*}{$E$} & AA & 0.498 & 0.047 & 0.051 & 0.257 & 0.083 & 0.134 & 1.070 \\
\hline & AT & 0.364 & 0.032 & 0.043 & ND & ND & ND & 0.439 \\
\hline Sum of AA herbicide concentrations & $\mathrm{AA}$ & 1.431 & 0.510 & 0.456 & 0.719 & 0.489 & 0.635 & 4.240 \\
\hline Sum of AT herbicide concentrations & AT & 1.477 & 0.701 & 0.609 & 0.139 & 0.515 & 0.373 & 3.814 \\
\hline
\end{tabular}

ND not detected 
were found in the sediment with the highest clay content (Table 10).

Furthermore, the organic matter content is another physical parameter affecting soil sorption capacity [4], but pond $E$ sediment with a high content of organic matter (Table 10) had the lowest herbicide contamination $\left(0.087 \mathrm{ng} \mathrm{g}^{-1}\right)$. This contradictory result is related to the nature of organic matter, which favors the adsorption of hydrophobic molecules especially [63], so that the adsorption of the herbicides detected in the water of pond $E$ was compromised by the hydrophilic characteristic of the herbicide molecules.

The molecular structures of the herbicides detected in the pond water indicated free electron pairs, giving the pesticides a basic character, according to Gilbert Newton Lewis [66]. When the sediment solution $\mathrm{pH}$ is lower than the pKb of the basic character herbicides, these compounds tend to absorb the clay particles and the functional groups forming the sediment cation exchange capacity (CEC) $[63,64,66,67]$ and contributing to sediment contamination since the herbicide pKbs ranging from 9.7 to 14 in the evaluated samples are higher than the sediment $\mathrm{pH}$ (Table 10).

\section{Conclusions}

Water samples of the affluent and studied fishing tanks, located in the micro-basins cultivated with sugarcane, were contaminated with the herbicides tebuthiuron, metolachlor, hexazinone, atrazine, ametryn, and clomazone, between June 2014 and May 2015.

Average tebuthiuron concentration was the most expressive (AA: $0.072 \mathrm{ng} \mathrm{mL}^{-1}$ and AT: $0.074 \mathrm{ng} \mathrm{mL}^{-1}$ ), but below the acceptable limit of $1.6 \mathrm{ng} \mathrm{mL}^{-1}$ recommended by the Canadian water quality guide, posing; therefore, there is no risk to human health. However, attention should be paid to the possibility of compromising the environmental health of watersheds occupied by sugarcane cultivation, since the herbicide tebuthiuron has qualified as a high to medium risk of environmental poisoning for aquatic macrophyte $L$. minor in a 0.3-m scenario.
Table 10 Chemical analysis, granulometric, and fertility of fish tank bottom sediment in the depth of 0.0 to $10.0 \mathrm{~cm}$

\begin{tabular}{|c|c|c|c|c|c|c|}
\hline & \multirow[t]{2}{*}{ Units } & \multicolumn{5}{|c|}{ Fee-fishing ponds } \\
\hline & & A & B & $\mathrm{C}$ & $\mathrm{D}$ & $E$ \\
\hline \multicolumn{7}{|c|}{ Chemical parameters } \\
\hline $\mathrm{pH}$ & $\mathrm{CaCl}_{2}$ & 5.0 & 5.4 & 5.3 & 4.5 & 4.7 \\
\hline M.O & $\mathrm{g} \mathrm{dm}^{3}$ & 10.0 & 13.0 & 18.0 & 9.0 & 45.0 \\
\hline$P$ & $\mathrm{mg} \mathrm{dm}^{3}$ & 17.0 & 98.0 & 35.0 & 5.0 & 31.0 \\
\hline K & mmolc dm ${ }^{3}$ & 1.2 & 2.4 & 0.9 & 1.0 & 2.3 \\
\hline $\mathrm{Ca}$ & mmolc dm ${ }^{3}$ & 18.0 & 37.0 & 25.0 & 7.0 & 23.0 \\
\hline $\mathrm{Mg}$ & mmolc dm ${ }^{3}$ & 11.0 & 19.0 & 9.0 & 3.0 & 12.0 \\
\hline $\mathrm{H}+\mathrm{Al}$ & mmolc dm ${ }^{3}$ & 31.0 & 34.0 & 31.0 & 28.0 & 64.0 \\
\hline SB & mmolc dm ${ }^{3}$ & 30.2 & 58.4 & 34.9 & 11.0 & 37.3 \\
\hline CEC & mmolc dm ${ }^{3}$ & 61.2 & 92.4 & 65.9 & 39.0 & 101.3 \\
\hline V & $\%$ & 49.0 & 63.0 & 53.0 & 28.0 & 37.0 \\
\hline \multicolumn{7}{|l|}{ Micronutrients } \\
\hline B & $\mathrm{mg} \mathrm{dm}^{3}$ & 0.2 & 0.1 & 0.2 & 0.2 & 0.3 \\
\hline $\mathrm{Cu}$ & $\mathrm{mg} \mathrm{dm}^{3}$ & 6.0 & 1.0 & 4.4 & 0.6 & 1.0 \\
\hline $\mathrm{Fe}$ & $\mathrm{mg} \mathrm{dm}^{3}$ & 135.0 & 162.0 & 168.0 & 236.0 & 218.0 \\
\hline $\mathrm{Mn}$ & $\mathrm{mg} \mathrm{dm}^{3}$ & 6.2 & 4.6 & 4.6 & 12.0 & 11.8 \\
\hline $\mathrm{Zn}$ & $\mathrm{mg} \mathrm{dm}{ }^{3}$ & 1.1 & 3.3 & 1.9 & 0.6 & 1.4 \\
\hline $\mathrm{S}-\mathrm{SO}_{4}$ & $\mathrm{mg} \mathrm{dm}^{3}$ & 5.0 & 4.0 & 13.0 & 3.0 & 7.0 \\
\hline Al & mmolc dm ${ }^{3}$ & 0.0 & 0.0 & 0.0 & 3.0 & 5.0 \\
\hline \multicolumn{7}{|c|}{ Physical parameters } \\
\hline Clay & $\mathrm{g} \mathrm{kg}^{-1}$ & 542.0 & 521.0 & 521.0 & 157.0 & 326.0 \\
\hline Silt & $\mathrm{g} \mathrm{kg}^{-1}$ & 168.0 & 100.0 & 195.0 & 2.0 & 392.0 \\
\hline Fine sand & $\mathrm{g} \mathrm{kg}^{-1}$ & 192.0 & 141.0 & 147.0 & 305.0 & 192.0 \\
\hline Coarse sand & $\mathrm{g} \mathrm{kg}^{-1}$ & 98.0 & 238.0 & 137.0 & 536.0 & 90.0 \\
\hline Textural class & & Clayey & Clayey & Clayey & Medium & Medium \\
\hline
\end{tabular}

M.O, organic matter; $\mathrm{P}$, phosphorus; $\mathrm{K}$, potassium; $\mathrm{H}+\mathrm{Al}$, hydrogen +aluminum; $\mathrm{SB}$, sum of bases; $C E C$, cation exchange capacity; $V$, baseline saturation percentage 
Additionally, for most of the evaluated ponds, contamination was higher in the water samples of the tributary stream compared to the fish tanks and during the highest rainfall periods. Other relevant factor affecting pond contamination levels is the excess of pesticides applied in the area during soil management practices.

In conclusion, the fish tank sediments were also contaminated with the herbicides metolachlor, tebuthiuron, hexazinone, and isoxaflutole. This statistically significant result shows a direct relationship between the herbicides found in the pond water and those present in the sediments, except for isoxaflutole.

Funding This work was supported by the Coordenação de Aperfeiçoamento de Pessoal de Nível Superior (CAPES).

\section{Compliance with ethical standards}

Conflict of interest On behalf of all authors, the corresponding author states that there is no conflict of interest.

\section{References}

1. Sharma A, Kumar V, Shahzad B, Tanveer M, Sldhu GPS, Handa $\mathrm{N}$ et al (2019) Worldwide pesticide usage and its impacts on ecosystem. SN Appl Sci 1:1446. https://doi.org/10.1007/s4245 2-019-1485-1

2. Sindicato Nacional da Indústria de Produtos para Defesa Agrícola - SINDIVEG (2016) https://www.sindiveg.org.br/. Accessed 17 April 2020

3. Steffen GPK, Steffen RB, Antoniolli ZI (2011) Contaminação do solo e da água pelo uso de agrotóxicos. Tecnológica 15:15-21. https://doi.org/10.17058/tecnolog.v15i1.2016

4. Ribeiro ML, Lourencetti C, Pereira SY, Marchi MRR (2007) Contaminação de águas subterrâneas por pesticidas: avaliação preliminar. Quím Nova 30:688-694. https://doi.org/10.1590/S0100 $-40422007000300031$

5. Spadotto CA (2006) Abordagem interdisciplinar na avaliação ambiental de agrotóxicos. Revista Núcleo de Pesquisa Interdisciplinar, pp 1-9. https://www.alice.cnptia.embrapa.br/alice /handle/doc/1026375. Accessed 15 June 2019

6. Armas ED, Monteiro RTR, Amâncio AV, Correa RMLE, Guercio MA (2005) The use of pesticides in sugar cane at the Corumbataí river basin and the risk of water pollution. Quím Nova 28:975-982

7. Grützmacher $D D$, Grützmacher $A D$, Agostinetto $D$, Loeck $A E$, Roman R, Peixoto SC et al (2008) Monitoramento de agrotóxicos em dois mananciais hídricos no sul do Brasil. Rev Bras Eng Agr Amb 12:632-637. https://doi.org/10.1590/S1415-4366200800 0600010

8. Marques MN, Cotrim MB, Pires MAF, Filho OB (2007) Avaliação do impacto da agricultura em áreas de produção ambiental, pertencentes à bacia hidrográfica do rio Ribeira de Iguapé, São Paulo. Quím Nova 30:1171-1178. https://doi.org/10.1590/S0100 $-40422007000500023$

9. Britto FB, Vasco AN, Pereira APS, Mello AV, Nogueire LC (2012) Herbicides in the upper Poxim River, Sergipe, and the risk of contamination of water resources. Rev Cienc Agron 43:390-398. https://doi.org/10.1590/S1806-66902012000200024
10. Jacomini AE, Camargo PB, Avelar WEP, Bonato PS (2011) Assessment of ametryn contamination in river water, river sediment, and mollusk bivalves in São Paulo State, Brazil. Arch Environ Contam Toxicol 60:452-461. https://doi.org/10.1007/s0024 4-010-9552-z

11. Moreira JC, Peres F, Simões AC, Pignati WA, Dores EC, Vieira SN et al (2012) Contaminação de águas superficiais e de chuva por agrotóxicos em uma região do estado do Mato Grosso. Cien Saude Colet 17:1557-1568. https://doi.org/10.1590/S1413 $-81232012000600019$

12. Possavatz J, Zeilhofer P, Pinto AA, Tives AL, Dores EFGC (2014) Resíduos de pesticidas em sedimento de fundo de rio na bacia hidrográfica do Rio Cuiabá, Mato Grosso, Brasil. Rev Ambient Água 9:83-96. https://doi.org/10.4136/ambi-agua.1263

13. Abell A, Juul S, Bonde JP (2000) Time to pregnancy among female greenhouse workers. Scand J Work Environ Health 26:131-136. https://doi.org/10.5271/sjweh.1031

14. Alavanja MCR, Bonner MR (2012) Occupational pesticide exposures and cancer risk: a review. J Toxicol Env Heal B Crit Rev 15:238-263. https://doi.org/10.1080/10937404.2012.632358

15. Alavanja MCR, Ross MK, Bonner MR (2013) Increased cancer burden among pesticide applicators and others due to pesticide Eexposure. CA Cancer J Clin 63:120-142. https://doi. org/10.3322/caac. 21170

16. Bortoluzzi EC, Rheinheimer DS, Gonçalves CS, Pellegrini JBR, Zanella R, Copetti ACC (2006) Contaminação de águas superficiais por agrotóxicos em função do uso do solo numa microbacia hidrográfica de Agudo, RS. Rev Bras Eng Agric Ambient 10:881-887. https://doi.org/10.1590/S1415-436620060004000 15

17. Bretveld RW, Hooiveld M, Zielhuis GA, Pellegrino A, Van Rooij IALM, Roeleveld N (2008) Reproductive disorders among male and female greenhouse workers. Reprod Toxicol 25:107-114. https://doi.org/10.1016/j.reprotox.2007.08.005

18. Burns CJ (2005) Cancer among pesticide manufacturers and applicators. Scand J Work Environ Health 31:9-17

19. Devillers J, Mombelli E, Samsera R (2011) Structural alerts for estimating the carcinogenicity of pesticides and biocides. SAR QSAR Environ Res 22:89-106. https://doi.org/10.1080/10629 36X.2010.548349

20. Grisolia CK (2005) Agrotóxicos: mutações, câncer e reprodução. UNB, Brasilia

21. Idrovo AJ, Sanin LH, Cole D, Chavarro J, Cáceres H, Narváez J et al (2005) Time to first pregnancy among women working in agricultural production. Int Arch Occup Environ Health 78:493-500. https://doi.org/10.1007/s00420-005-0615-9

22. Roberts EM, English PB, Grether JK, Windham GC, Somberg L, Wolff C (2007) Maternal residence near agricultural pesticide applications and autism spectrum disorders among children in the California Central Valley. Environ Health Perspect 115:14821489. https://doi.org/10.1289/ehp.10168

23. Rohr JR, Mccoy KA (2010) A qualitative meta-analysis reveals consistent effects of atrazine on freshwater fish and amphibians. Environ Health Perspect 118:20-32. https://doi.org/10.1289/ ehp.0901164

24. Associação Brasileira De Normas Técnicas - ABNT (1987) NBR 9898: Preservação e técnicas de amostragem de efluentes líquidos e corpos receptores. Rio de Janeiro, 1-22.

25. Companhia Ambiental do Estado de São Paulo - CETESB (2011) Guia nacional de coletas e preservação de amostras-água, sedimento, comunidades aquáticas e efluentes líquidos. Brasília: ANA, pp 31-325

26. Associação Brasileira De Normas Técnicas - ABNT (1984) NBR 7181: Solo - Análise Granulométrica. Rio de Janeiro, pp 1-13

27. Embrapa (1997) Manual de Métodos de Análise de Solos. $2^{\circ}$ ed. Centro Nacional de Pesquisa de Solo: Rio de Janeiro, pp 1-212 
28. Spadotto CA, Gomes MAF, Luchini LC, Andréa MM (2004) Monitoramento do risco ambiental de agrotóxicos: princípios e recomendações. Embrapa Meio Ambiente, vol 0, pp 8-29 https://ainfo.cnptia.embrapa.br/digital/bitstream/CNPMA /5810/1/documentos_42.pdf. Accessed 10 June 2019

29. Kouzayha A, Rabaa AR, Iskandarani MA, Beh D, Budzinski $H$, Jaber $F$ (2012) Multiresidue method for determination of 67 pesticides in water sample using solid-phase extraction with centrifugation and gas chromatography-mass spectrometry. Am J Analyt Chem 3:257-265. https://doi.org/10.4236/ ajac.2012.33034

30. Pihlström T (2011) Method validation and quality control procedures for pesticide residues analysis in food and feed. Document no SANCO/12495/2011, pp 4-41. https://www.eurlpestic ides.eu/library/docs/allcrl/AqcGuidance_Sanco_2011_12495 .pdf. Accessed 01 June 2019

31. Matos AKA, Carbonari CA, Velini ED, Gomes GLGC, Trindade MLB, Macedo GC (2015) Vinasse effect on herbicides clomazone and tebuthiuron availability in different kinds of soils. Planta Daninha 33:771-778. https://doi.org/10.1590/S0100-8358201500 0400015

32. Ribani M, Bottoli CBG, Collins CH, Jardim ICSF (2004) Validação em métodos cromatográficos e eletroforéticos. Quím Nova 27:771-780. https://doi.org/10.1590/S0100-404220040005000 17

33. Organization for Economic Cooperation and Development OECD (2002) Lemna sp. Growth Inhibition Test, in: GUIDELINE for testing of chemicals

34. Associação Brasileira De Normas Técnicas - ABNT (2016) NBR 15499: Ecotoxicologia aquática-toxicidade crônica de curta duração-Método de ensaio com peixes. Rio de Janeiro, pp $1-23$

35. Hamilton MA, Russo RC, Thurston V (1977) Trimed SpermanKarber method for estimating medial lethal concentrations in toxicology bioassays. Environ Sci Technol 7:714-719. https://doi. org/10.1021/es60130a004

36. Parker RD, Jones RD, Nelson HP (1995) GENEEC: a screening model for pesticide environmental exposure assessment. ASAE, 485-490.

37. Urban DJ, Cook NJ (1986) Hazard evaluation division—standard evaluation procedure ecological risk assessment. USEPA Publication EPA/540/09-88-035

38. Solomon KR, Dalhoff K, Volz D, Kraak GVD (2014) Effects of herbicides on fish. Fish Physiol 33:369-409. https://doi.org/10.1016/ B978-0-12-398254-4.00007-8

39. Manrique WG, Fiqueirego MAP, Machado-Neto JG (2013) Dissipation and environmental risk of fipronil on aquatic environment. The Biologist (Lima) 11:107117

40. Goktepe I, Portier R, Ahmedna M (2004) Ecological risk assessment of Neembased pesticides. J Environ Sci Health B 39:311320. https://doi.org/10.1081/pfc-120030244

41. Grisa FT, Ortiz KS, Geremias D (2008) Avaliação da contaminação por organofosforados em águas superficiais no município de Rondinha - Rio Grande do Sul. Quím Nova 31:1631-1635. https ://doi.org/10.1590/S0100-40422008000700006

42. Almeida MD, Pereira TSB, Batlouni SR, Boscolo CNP, Almeida EA (2018) Estrogenic and anti-androgenic effects of the herbicide tebuthiuron in male Nile tilapia (Oreochromis niloticus). Aquat Toxicol 194:86-93. https://doi.org/10.1016/j.aquat ox.2017.11.006

43. Botelho RG, Monteiro SH, Christofoletti CA, Moura-Andrade GCR, Tornisielo VL (2015) Environmentally relevant concentrations of atrazine and ametrine induce micronuclei formation and nuclear abnormalities in erythrocytes of fish. Arch Environ Contam Toxicol 69:577-585. https://doi.org/10.1007/s0024 4-015-0171-6
44. Crestani M, Menezes C, Glusczak L, Miron DS, Spanevello R, Silveira A (2007) Effect of clomazone herbicide on biochemical and histological aspects of silver catfish (Rhamdia quelen) and recovery pattern. Chemosphere 67:2305-2311. https://doi. org/10.1016/j.chemosphere.2006.09.070

45. Crestani M, Menezes C, Glusczak L, Miron DS, Lazzari R, Duarte MF et al (2006) Effects of clomazone herbicide on hematological and some parameters of protein and carbohydrate metabolism of silver catfish Rhamdia quelen. Ecotoxicol Environ Safe 65:48-55. https://doi.org/10.1016/j.ecoenv.2005.06.008

46. Nieves-Puigdoller K, Björnsson BT, McCormick SD (2007) Effects of hexazinone and atrazine on the physiology and endocrinology of smolt development in Atlantic salmon. Aquat Toxicol 84:27-37. https://doi.org/10.1016/j.aquatox.2007.05.011

47. Velisek J, Stara A, Zuskova E, Kubec J, Buric M, Kouba A (2018) Chronic toxicity of metolachlor OA on growth, ontogenetic development, antioxidant biomarkers and histopathology of early life stages of marble crayfish. Sci Total Environ 643:14561463. https://doi.org/10.1016/j.scitotenv.2018.06.309

48. Velisek J, Stara A, Zuskova E, Kubec J, Buric M, Kouba A (2019) Effects of s-metolachlor on early life stages of marbled crayfish. Pestic Biochem Physiol 153:87-94. https://doi.org/10.1016/j. pestbp.2018.11.007

49. Pinheiro MNM, Hortêncio MM, Evangelista RAO (2012) Distribuição espacial da biodiversidade de macrófitas aquáticas nos lagos da região Nordeste do Estado de Roraima. Revista Geonorte 1:162-174. ID: 163213332.

50. Stephenson GR, Solomon KR (2007) Pesticides and the environment. Canadian Network of Toxicology Centres Press Guelph, Ontario

51. University of Hertfordshire - UH (2016) The University of Hertfordshire agricultural substances database background and support information. https://sitem.herts.ac.uk/aeru/ppdb/en/ index.htm. Accessed 20 May 2020

52. Di Bernardo DA, Paschoalato CFR, Martinez MS, Ballejo RR, Di Bernardo L (2011) Removal of diuron and hexazinone from Guarany Aquifer groundwater. Braz J Chem Eng 28:415-424. https ://doi.org/10.1590/S0104-66322011000300007

53. Dores EFGC, Carbo L, Ribeiro ML, De-Lamonica-Freire E (2008) Pesticide levels in ground and surface waters of Primavera do Leste region, Mato Grosso, Brazil. J Chromatogr Sci 46:585-590. https://doi.org/10.1093/chromsci/46.7.585

54. Dores EFGC, Spadotto CA, Weber OLS, Carbo L, Vecchiato AB, Pinto AA (2009) Environmental behaviour of metolachlor and diuron in a tropical soil in the central region of Brazil. Water Air Soil Poll 197:175-183. https://doi.org/10.1007/s1127 0-008-9801-1

55. Gomes MAF, Spadotto CA, Lanchotte VL (2001) Ocorrência do herbicida tebuthiuron na água subterrânea da microbacia do Córrego Espraiado, Ribeirão Preto - SP. Pesticidas Revista de Ecotoxicologia e Meio Ambiente 11:65-76. https://doi.org/10.5380/ pes.v11i0.3136

56. Mariot E, Webwe OLS, Spadotto CA, Dores EFGC (2009) Uso do índice LIX na previsão de lixiviação dos pesticidas metolacloro, endossulfam, clorpirifós, carbendazim e diuron. Pesticidas: Revista de Ecotoxicologia e Meio Ambiente 19:57-64. https:// ainfo.cnptia.embrapa.br/digital/bitstream/item/35260/1/11039 .pdf. Accessed 01 March 2020

57. Correia NM, Braz BA, Fuzita WE (2010) Eficácia de herbicidas aplicados nas épocas seca e úmida para o controle de Merremia aegyptia na cultura da cana-de-açúcar. Planta Daninha 28:631-642. https://doi.org/10.1590/S0100-835820100003000 21

58. Procópio SO, Silva AA, Vargas L (2008) Manejo e controle de plantas daninhas em cana-de-açúcar. Passo Fundo, Embrapa Trigo 
59. Rodrigues BN, Almeida FS (2005) Guia de herbicidas. Londrina, Grafmarke

60. Hinkle DE, Wiersma WJSG (2003) Applied statistics for the behavioral sciences. Houghton Mifflin, Boston

61. Embrapa (2006) Sistema Brasileiro de Classificação de Solos. https://www.embrapa.br/busca-de-publicacoes/-/publi cacao/1094003/sistema-brasileiro-de-classificacao-de-solos. Accessed 01 March 2020

62. Holvoet KMA, Seuntjens P, Vanrolleghem PA (2007) Monitoring and modeling pesticide fate in surface waters at the catchment scale. Ecol Model 209:53-64. https://doi.org/10.1016/j.ecolm odel.2007.07.030

63. Christoffoleti PJ, Ovejero RFL, Damin V, Carvalho SJP, Nicolai M (2008) Comportamento dos herbicidas aplicados ao solo na cultura de cana-de-açúcar.https://edisciplinas.usp.br/plugi nfile.php/3825040/mod_resource/content/1/Livro\%2520Herbic idas\%2520no\%2520Solo.pdf. Accessed 20 June 2019

64. Firmino LE, Tuffi Santos LD, Ferreira LR, Ferreira FA, Quirino ALS (2008) Movimento do herbicida imazapyr no perfil de solos tropicais. Planta Daninha 26:223-230. https://doi.org/10.1590/ S0100-83582008000100023

65. Gomes MAF, Spadotto CA, Pereira AS, Matallo MB, Luchini LC (2006) Movimento do herbicida tebutiuron em dois solos representativos das áreas de recarga do aquífero Guarani. Rev Bras Eng Agríc Ambient 10:479-483. https://doi.org/10.1590/S1415 $-43662006000200032$

66. Russel JB (1994) Química Geral. Makron Books, São Paulo

67. Alterman MK, Jones AP (2003) Herbicidas: fundamentos fisiológicos y bioquímicos del modo de acción. Ediciones Universidad Catolica de Chile, Santiago

Publisher's Note Springer Nature remains neutral with regard to jurisdictional claims in published maps and institutional affiliations. 